\title{
Delayed corticosteroid hypersensitivity: a clinical management proposal
}

\author{
${ }^{1}$ Allergy Clinic, Casa della Salute, Genoa, Italy \\ ${ }^{2}$ Allergy Clinic, Asl 2 Savona, Savona, Italy
}

\section{KEY wORDS}

Steroid allergy; delayed hypersensitivity; drug allergy; systemic contact dermatitis; allergic contact dermatitis.

\author{
Corresponding author \\ Susanna Voltolini \\ Allergy Clinic \\ Casa della Salute \\ largo XII ottobre 62 \\ Genoa, Italy \\ E-mail: Susanna.v@alice.it
}

\section{Doi}

10.23822/EurAnnACI.1764-1489.164

\begin{abstract}
Summary
Background. Different clinical pictures are related to corticosteroids (CS) non immediate hypersensitivity and the frequency of these reactions can be underestimated. The classification of CS in 3 groups and the identification of two patient's profiles has been proposed by Baeck to help clinicians in the management of these cases. Methods. Data of 14 patients with clinical history of delayed reactions to various $C S$ and positive skin test andlor oral challenge are retrospectively analyzed. Results. Three different patterns of patients are identified evaluating history, clinical picture and tests results. The first one (6pts, 43\%) is characterized by cutaneous andlor mucosal reaction due to inhaled Budesonide and patch test positive only to topical molecules belonging to the group 1 of CS. The second pattern (4 pts) has clinical history of local and systemic skin reactions to the topic and parenteral administration of the same or other steroid drugs. Patients belonging to the third pattern (4 pts) have a history of systemic reactions to general administration of CS without previous contact reaction. Patterns 2 and 3 show a wide sensitization to molecules belonging to the 3 groups of CS. All the patients show patch test positive to Budesonide. Conclusions. Although the lack of standardization, the allergy workup proves useful to differentiate patients sensitized to one or few molecules from polysensitized and to identify the culprit drugs. Intradermal and challenge test are necessary to complete the diagnostic workup. The results suggest the possibility of a different management of patients. Patients of pattern one can be only patch tested with a limited series of CS belonging to the 3 groups. They don't need an extensive exclusion of steroids use. The pattern 2 and 3 must be submitted instead to a complete allergological individual evaluation to identify alternative tolerated drugs, because of the risk of systemic reactions. The Baeck's classification shows limited usefulness in these cases.
\end{abstract}

\section{Introduction}

Although it seems a paradox, several cases of allergy to corticosteroids (CS) are described and both the IgE-mediated and the cellular type IV mechanisms are involved, causing immediate and delayed hypersensitivity reactions $(1,2)$ respectively. Steroids hypersensitivity is rare despite their wide use, in particular immediate reactions for which the prevalence is $0.1-0.3 \%$ (3); delayed reactions are more frequent with prevalence being 0.1 5\% (4). However, the reactions could be under-diagnosed, since the clinical presentation can be sometimes confused with the disease requiring the steroid treatment. Delayed reactions can be due to topical application (allergic contact dermatitis, ACD) or can be the consequence of systemic administration of steroid to a patient previously sensitized. This is known as systemic contact dermatitis (SCD) and it can affect the 5\% of cases with CS contact allergy (4).

Every CS molecule can cause sensitization and both topic and systemic administration can elicit symptoms. Three generations of steroids, in addition to cortisol (hydrocortisone) and cortisone (11-deidrocortisol) are available. The first classification (Coopman 1989) in 4 groups in function of their structure and contact-allergenic properties, has been modified by Baeck in 2011 into three groups (5) (table I). Steroids belonging to 
group 1 are more prone to cause hypersensitivity due to the absence of $\mathrm{C}_{16}$-methyl substitution and non-halogenation leading to an easier link to proteins and consequent aptenization. In the same study, Baeck identified two profile of patients: profile 1, patients who react to steroids from one group only, for whom the cross-reaction seems due to electrostatic fields and profile 2, patients who react to two or three groups because of the immunological recognition of the whole skeleton structure of steroid molecule (5). How this classification is useful in the clinical practice for predicting reactions is not clear. In fact, the cross-reactivity among steroids is important for delayed reactions, while less is known for immediate ones. Moreover, due to the lacking guidelines, the standardisation of diagnostic tests is still a problem. The study retrospectively describes 14 cases of different delayed reactions, with the aim to better understand how to manage these patients in the clinical practice.

Secondary purpose is to compare the clinical pattern of these patients with the two patients profiles proposed by Baeck (5).

\section{Materials and methods}

Data of 14 patients with delayed steroid reactions confirmed by positive skin test and/or oral challenge were retrospectively collected. The mean age of the group was 60 years, nine were female. Written informed consent was obtained from each patient. Almost all patients (13 out of 14) had been patch tested with the CS molecules listed in table II, representative of the three groups of steroids according to the Baeck classification (5), with the addition of other drugs based on the individual clinical history. Standardized extracts for patch test were available only for a few molecules (Budesonide, Hydrocortisone 17 and 21, Desametasone), while for the others the commercial drugs were used according to the European guidelines criteria (6). The subsequent diagnostic process was personalized on the history and the clinical feature of each patient. Ten patients underwent to skin prick test (SPT), intradermal test (ID) with immediate and late reading (until 96 hours) and oral challenge (OC) for one or more drugs (7).

Table I - Corticosteroid classification. Adapted from Baeck (5).

\begin{tabular}{|c|c|c|}
\hline Group 1 & Group 2 & Group 3 \\
\hline Budesonide & Triamcinolone & Alclometasone dipropionate \\
\hline Cloprednol & Amcinonide & Beclomethasone dipropionate \\
\hline Cortisone acetate & Desonide & Betamethasone \\
\hline Dichlorisone acetate & Fluchloronide & Betamethasone 17-valerate \\
\hline Difluprednate & Flumoxonide & Betamethasone dipropionate \\
\hline Fludrocortisone acetate & Flunisolide & Betamethasone sodium phosphate \\
\hline Hydrocortisone & Halcinonide & Desoximetasone \\
\hline Hydrocortisone aceponate & Triamcinolone acetonide & Dexamethasone \\
\hline Hydrocortisone acetate & Triamcinolone benetonide & Dexamethasone acetate \\
\hline Hydrocortisone 17-butyrate & Triamcinolone diacetate & Dexamethasone sodium phosphate \\
\hline Hydrocortisone 21-butyrate & Triamcinolone hexacetonide & Diflucortolone valerate \\
\hline Hydrocortisone hemisuccinate & & Diflorasone diacetate \\
\hline Methylprednisolone acetate & & Fluocortolone capraylate \\
\hline Methylprednisolone aceponate & & Fluocortolone pivalate \\
\hline Methylprednisolone hemisuccinate & & Fluocortolone acetate \\
\hline Prednicarbate & & Halometasone \\
\hline Prednisolone & & Meprednisone \\
\hline Prednisolone caproate & & Fluticasone propionate \\
\hline Prednisolone pivalate & & Mometasone furoate \\
\hline \multicolumn{3}{|l|}{ Prednisolone sodium metasulfobenzoate } \\
\hline \multicolumn{3}{|l|}{ Prednisolone succinate } \\
\hline \multicolumn{3}{|l|}{ Prednisone } \\
\hline Tixocortol pivalate & & \\
\hline
\end{tabular}


Table II - Panel of steroids used for patch test.

\begin{tabular}{ccc}
\hline Group 1 & Group 2 & Group 3 \\
\hline Budesonide & Triamcinolone acetonide & Betamethasone dipropionate \\
Hydrocortisone & Flunisolide & Betamethasone sodium-phosphate \\
Hydrocortisone 17 butyrate & & Desoxymethasone \\
Hydrocortisone 21 butyrate & & \\
Methylprednisolone acetate & & \\
Methylprednisolone hemisuccinate & & \\
Prednisolone & & \\
\hline
\end{tabular}

Table III - Characteristics of patients belonging to the Pattern 1.

\begin{tabular}{|c|c|c|c|c|c|c|c|}
\hline $\mathbf{N}^{\circ}$ & Age & Sex & Culprit drug & Clinical presentation & Positive patch test & Intradermal test & Oral challenge \\
\hline 1 & 55 & F & $\begin{array}{l}\text { Budesonide } \\
\text { aerosol }\end{array}$ & $\begin{array}{l}\text { Face and neck erithema and } \\
\text { oedema }\end{array}$ & $\begin{array}{l}\text { Budesonide } \\
\begin{array}{c}\text { Hydrocortisone- } \\
\text { 21-acetate }\end{array}\end{array}$ & $\begin{array}{l}\text { Hydrocortisone } \\
\text { succinate negative }\end{array}$ & Prednisone negative \\
\hline 2 & 36 & F & $\begin{array}{l}\text { Budesonide } \\
\text { aerosol }\end{array}$ & $\begin{array}{l}\text { Face and neck erithema } \\
\text { Lips oedema }\end{array}$ & Budesonide & $\begin{array}{c}\text { Betamethasone } \\
\text { phosphate negative }\end{array}$ & $\begin{array}{l}\text { Deflazacort } \\
\text { negative }\end{array}$ \\
\hline 3 & 23 & F & $\begin{array}{l}\text { Budesonide } \\
\text { aerosol }\end{array}$ & Oral and face oedema & $\frac{\text { Budesonide }}{\begin{array}{c}\text { Hydrocortisone- } \\
\text { butyrate }\end{array}}$ & N. D. & N. D. \\
\hline 4 & 42 & $\mathrm{~F}$ & $\begin{array}{l}\text { Budesonide } \\
\text { aerosol }\end{array}$ & $\begin{array}{l}\text { Lips oedema } \\
\text { Stomatitis }\end{array}$ & $\frac{\text { Budesonide }}{\begin{array}{c}\text { Hydrocortisone- } \\
\text { butyrate }\end{array}}$ & N. D. & N. D. \\
\hline 5 & 49 & M & $\begin{array}{c}\text { Nasal } \\
\text { Budesonide }\end{array}$ & $\begin{array}{l}\text { Face oedema and mucosal } \\
\text { oedema }\end{array}$ & $\underline{\text { Budesonide }}$ & $\begin{array}{c}\text { Betamethasone } \\
\text { phosphate negative }\end{array}$ & $\begin{array}{c}\text { Betamethasone } \\
\text { phosphate negative }\end{array}$ \\
\hline 6 & 58 & F & $\begin{array}{l}\text { Budesonide } \\
\text { aerosol }\end{array}$ & Lips oedema & $\underline{\text { Budesonide }}$ & N. D. & N. D. \\
\hline
\end{tabular}

The culprit drug is underline when positive; N.D.: not done.

\section{Results}

According to clinical history, culprit drugs and test results, the patients were divided into three patterns.

\section{Pattern 1 (see table III)}

Six patients with local reaction of various degree of severity appeared after Budesonide bronchial inhalation ( 5 cases) or nasal spray (1 case).

Patch test confirmed the causal relationship with Budesonide. The cross-reactivity was limited to a few molecules belonging to the same group of CS such as Hydrocortisone 17-butyrate and Hydrocortisone 21-acetate, both used locally. Prick test, ID and oral challenge test performed with a set of different molecules resulted negative for three patients.

\section{Pattern 2 (see table IV)}

Four patients with a history of ACD due to steroids other than Budesonide, for topic skin use. Two of them presented systemic skin reactions after parenteral administration of other steroids. Patch test showed a wide polisensitization in three patients. Patient number 7 underwent intradermal test only (negative for the culprit but positive for a not suspected molecule) while oral challenge protracted for two days was necessary to confirm the history of systemic dermatitis elicited by oral desamethasone.

\section{Pattern 3 (see table V)}

Four patients with systemic delayed urticaria or exanthema after administration of different systemic drugs, without any previous local reaction to topical products. 
Table IV - Characteristics of patients belonging to the pattern 2.

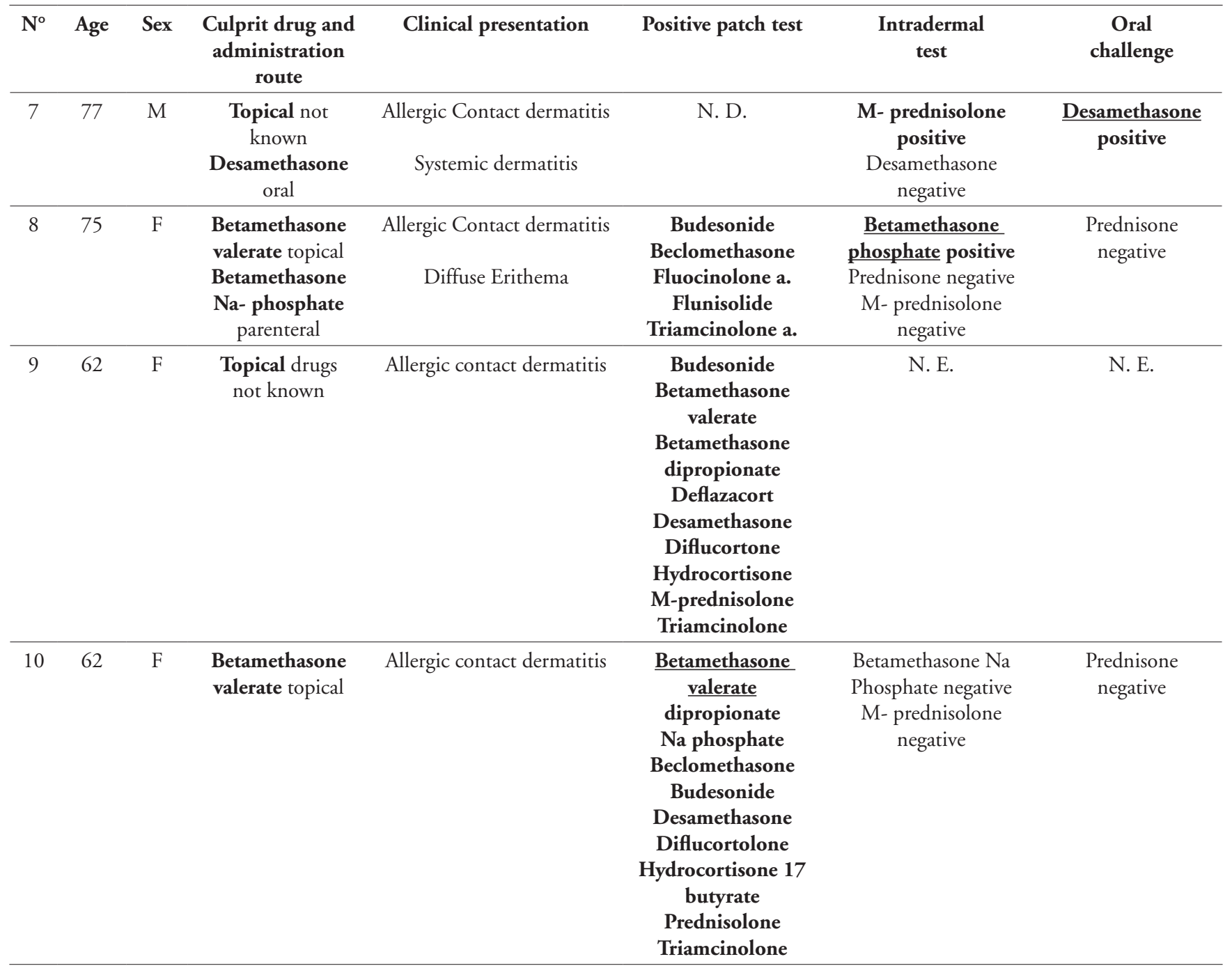

The culprit drug is underline when positive; N.D.: not done.

They showed wide sensitization to the patch test panel, comprehensive of the suspected drug, while intradermal test was negative to the culprit drug in three cases and challenge test gave doubtful results.

\section{Discussion}

Drug allergy reactions to steroids are not so rare, mainly the delayed ones. Allergic contact dermatitis is the most frequent clinical picture: it has to be considered in patients using cutaneous topical steroids with worsening of dermatitis and also in patients using inhaled steroid and developing mucositis, cutaneous eczema or angioedema involving nasal or oral mucosa, lips, face and neck. Moreover, a systemic cutaneous reaction can be caused by systemic administration, even after a single dose of steroid drug, used for example for intra-articular injection $(1,2,4,8)$.

The cases analyzed in this study confirm that delayed hypersensitivity to CS can be caused by different patterns of sensitization and can occur with different clinical picture. One of the most frequent (pattern 1:43\%) is the muco-cutaneous reaction to inhaled products, with Budesonide resulting the sensitizer molecule and a cross-reactivity limited to a few similar topical steroids, belonging to the same group. The clinical consequence is that these patients don't seem to be prone to develop systemic reactions and usually they should not limit the use of steroids. In the second group of patients a previous local reaction to a cutaneous product can lead 
Table $V$ - Characteristics of patients of pattern 3.

\begin{tabular}{|c|c|c|c|c|c|c|c|}
\hline $\mathbf{N}^{\circ}$ & Age & Sex & $\begin{array}{l}\text { Culprit drug and } \\
\text { administration } \\
\text { route }\end{array}$ & $\begin{array}{c}\text { Clinical } \\
\text { presentation }\end{array}$ & Positive patch test & $\begin{array}{c}\text { Intradermal } \\
\text { test }\end{array}$ & $\begin{array}{c}\text { Oral } \\
\text { challenge }\end{array}$ \\
\hline 11 & 68 & $\mathrm{M}$ & $\begin{array}{l}\text { Triamcinolone } \\
\text { intraarticular }\end{array}$ & Delayed urticaria & $\begin{array}{c}\text { Triamcinolone } \\
\text { Desamethasone } \\
\text { Diflucortolone } \\
\text { Betamethasone Na phosphate } \\
\text { Betamethasone valerate } \\
\text { Betamethasone dipropionate } \\
\text { Budesonide } \\
\text { Hydrocortisone } 17 \text { butyrate } \\
\text { M-prednisolone a } \\
\text { M-prednisolone } s \text {. }\end{array}$ & $\begin{array}{c}\text { M- prednisolone } \\
\text { positive } \\
\text { Prednisone negative } \\
\text { Triamcinolone negative } \\
\text { Betametasone } \mathrm{Na} \\
\text { phosphate negative }\end{array}$ & $\begin{array}{c}\text { Prednisone } \\
\text { negative }\end{array}$ \\
\hline 12 & 81 & $\mathrm{M}$ & $\begin{array}{l}\text { Betamethasone } \\
\text { Na phosphate } \\
\text { intraarticular }\end{array}$ & Delayed urticaria & $\begin{array}{l}\text { Betamethasone } \\
\text { Budesonide } \\
\text { Beclomethasone } \\
\text { Desamethasone } \\
\text { Diflucortone } \\
\text { Fluocinolone } \\
\text { Flunisolide } \\
\text { Hydrocortisone } \\
\text { Methylprednisone } \\
\text { Triamcinolone }\end{array}$ & $\begin{array}{c}\text { Betametasone } \mathrm{Na} \\
\text { phosphate positive } \\
\text { M-prednisolone } \\
\text { hemisucinate negative }\end{array}$ & $\begin{array}{c}\text { Deflazacort } \\
\text { doubtful }\end{array}$ \\
\hline 13 & 71 & $\mathrm{~F}$ & $\begin{array}{l}\text { M-prednisolone } \\
\text { parenteral } \\
\text { Deflazacort oral }\end{array}$ & Diffuse exanthema & $\begin{array}{c}\text { Budesonide } \\
\text { Hydrocortisone } 17 \text { butyrate } \\
\text { Deflazacort }\end{array}$ & $\begin{array}{c}\text { M- prednisolone } \\
\text { negative } \\
\text { Betametasone } \mathrm{Na} \\
\text { phosphate negative }\end{array}$ & $\begin{array}{l}\text { Betametasone } \\
\text { Na phosphate } \\
\text { negative }\end{array}$ \\
\hline 14 & 76 & M & $\begin{array}{c}\text { Betamethasone } \\
\text { Na-Ph parenteral } \\
\text { Desamethasone } \\
\text { oral } \\
\text { Beclomethasone } \\
\text { rectal }\end{array}$ & $\begin{array}{c}\text { Urticaria } \\
\text { Immediate rash } \\
\text { Urticaria }\end{array}$ & $\begin{array}{c}\text { Budesonide } \\
\text { Beclomethasone } \\
\text { M- prednisolone }\end{array}$ & $\begin{array}{l}\text { M- prednisolone } \\
\text { negative } \\
\text { Betametasone } \mathrm{Na} \\
\text { phosphate negative }\end{array}$ & $\begin{array}{l}\text { Prednisone } \\
\text { doubtful }\end{array}$ \\
\hline
\end{tabular}

The culprit drug is underline when positive; N.D.: not done.

to systemic symptoms when the drug is administered by systemic route; this could be triggered even by drugs different from the sensitizer. These patients show sensitization to a wide range of molecules belonging to different chemical groups of CS.

The third pattern is characterized by a history of delayed urticaria or exanthema after systemic administration of various steroid drugs by different route (oral, intra-articular, intramuscular, rectal). No previous topical reactions are reported and patients show sensitization to many molecules over the culprit. All the patients are sensitized to Budesonide even in the absence of previous contact.

Similarly to other studies (9), this report confirms the validity of the Baek's hypothesis: some patients seem to recognize only the lateral chain of the steroid molecule with limited cross-reactivity, while others seem to recognize the skeletal structure of the molecule, with wide cross-reactivity. Some further differences among these patients can be identified in the clinical history, in the way of sensitization and in test results.

This may suggest different management of patients: pattern 1 may have a few limitations related on the use of topical molecules only. For the two other patterns, due to the broad sensitization spectrum, it's necessary to find one or more alternative molecules to avoid the risk of systemic reactions.

As usual in drug allergy, the diagnostic workup depends on the way of administration of the drugs and the timing of onset of symptoms. The choice of the drugs to be tested depends on the clinical history and on the need of individual patient. Unfortunately, the diagnostic workup is not standardized yet. Moreover, the anti-inflammatory activity of CS can reduce the sensitivity, requiring different kinds of test (patch, intradermal and challenge test) to confirm the role of the drug as cause of reaction. 


\section{Conclusions}

The results of this study show that in the clinical practice it's important to set up a workup tailored to the pattern of patients, evaluating multiple molecules for the assessment of the individual sensitization/tolerance profile. The classification of steroids in chemical groups appears to be of limited usefulness, due to the great variability of reactivity and sensitization of the patients. Moreover, it's not applicable to systemic corticosteroids and does not seem to be useful to predict $\operatorname{SCD}(10,11)$.

The study has some limitations, mainly as a consequence of its retrospective design and the limited number of patients.

Nevertheless, studies like this could increase awareness of steroids hypersensitivity reactions and help clinicians on the management (11).

\section{Acknowledgements}

The authors would like to thank the Allergy Unit of San Martino Policlinic in Genoa, Italy

\section{Conflict of interests}

The authors declare that they have no conflict of interests.

\section{References}

1. Torres MJ, Canto G. Hypersensitivity reactions to corticosteroid. Curr Opin Allergy Clin Immunol 2010;10:273-79.
2. Otani IM, Banerji A. Immediate and Delayed Hypersensitivity Reactions to Corticosteroids: Evaluation and Management. Curr Allergy Asthma Rep 2016;16(3):18.

3. De Sousa NG, Santa-Marta C, Morais-Almeida M. Systemic corticosteroid hypersensitivity in children. J Investig Allergol Clin Immunol 2010;20:529-32.

4. Baeck M, Goossens A. Systemic contact dermatitis to corticosteroids. Allergy 2012;67:1580-5.

5. Baeck M, Chemelle JA, Goossens A, Nicolas JF, Terreux R. Corticosteroid cross-reactivity: clinical and molecular modelling tools. Allergy 2011;66(10):1367-74.

6. Johansen JD, Aalto-Korte K, Agner T, et al. European Society of Contact Dermatitis guideline for diagnostic patch testing - recommendations on best practice. Contact Dermatitis 2015;73:195-212.

7. Baker A, Empson M, The R, Fitzharris P. Skin testing for immediate hypersensitivity to corticosteroids: a case series and literature review. Clin Exp Allergy 2015;45(3):669-76.

8. Nucera E, Buonomo A, Pollastrini E, et al. A Case of Cutaneous Delayed-Type Allergy to Oral Dexamethasone and to Betamethasone. Dermatology 2002;204:248-50.

9. Berbegal L, DeLeon FJ, Silvestre JF. Corticosteroid Hypersensitivity Studies in a Skin Allergy Unit. Actas Dermosifilogr 2015;106(10):816-22.

10. Santos-Alarcón S, Benavente-Villegas FC, Farzanegan-Miñano R, Pérez-Francés C, Sánchez-Motilla JM, Mateu-Puchades A. Delayed hypersensitivity to topical and systemic corticosteroids. Contact Dermatitis 2017;78:83-99.

11. Knarborg M, Bendstrup E, Hilberg O. Increasing awareness of corticosteroid hypersensitivity reactions is important. Respirol Case Rep 2013;1(2):43-5. 